\title{
Global financial markets: financial deregulation and crises
}

\author{
Alicia Giron and Eugenia Correa
}

\section{Introduction}

Like the 1929 crisis, the current financial crisis will be remembered as one of the most serious in the history of world capitalism. Michel Camdessus has described it as the first global crisis of the 21st century, beginning in Mexico in 1994-1995 and continuing until 1997 or thereabouts with the Asian crisis. The Mexican and Asian financial crises coincide with deregulation and liberalization processes which in some cases had already started a decade or two before. These processes have been accompanied by changes in production structures and international trade, which are revealing limits to what can be done.

The increasing difficulty experienced by the financial authorities of the major economies and by international financial bodies in limiting the most devastating effects of
Alicia Giron is Director of the Economic Research Institute of the Autonomous University of Mexico, Ciudad Universitaria, Coyacan C:P:04510. Email: alicia@ servidor.unam.mx. Her publications include Cincuenta Anos de la Deuda Externa and Fin de Siglo y Deuda Externa: Historia sin Fin.

Eugenia Correa is Professor of Economics at the same university. Address: Aguayo 66 El Carmen-Coyoacan 04100 Mexico D.F. Email: correa@servi dor.unam.mx. She has been working for 20 years on themes connected with economic development and the economics of finance. the economic policies of nation states them-

This paper analyses the chief transformations in the financial markets over the past 25 years. These changes are typical of a financial-globalization process and are factors in the rrent financial instability and fragility. Finangulation has made it gradually imposfor nation-states to control their money rcing them to shoulder enormous losses in the form of public debt. At the same time they do not appear to be taking steps to acquire the instruments needed to limit the more destructive effects of instability in the monetary, exchange and credit fields. Financial globalization has not become a regulatory process, nor has it acquired the institutional form at the national and international levels which would bring about financial stability.

One of the characterevents on the world economy makes it difficult, in turn, to handle banking and financial crises. The current institutional composition of the markets, the deregulated nature of those markets and the vast liquid assets in private hands have even placed limits on concerted action by national governments. At the same time, the increasing number of national financial crises has put an end to the stabilization model promoted by the International Monetary Fund and istic features of the financial-deregulation process has been the occurrence of banking crises. These arise when the active management of balances comes up against currency mismatch problems; when credit is concentrated in certain sectors (for example, oil or real estate) or companies; when real interest rates are high during periods of lower economic growth; when leverage levels are high as a result of rapid privatizations or takeovers; or when these factors are combined. 
The question of banking crises will therefore be examined in the second part of this paper.

The third part of the paper surveys the new level of concentration prevailing on financial markets, the aim being to show how sources of national and international liquidity continue to remain highly concentrated. The Asian financial crisis has boosted concentration even further, with the result that true multinational financial mega-conglomerates have arisen, leading to overall consolidation of the sector. The paper concludes by stressing the importance of state monetary and credit management as the way to achieve a stable relationship between growth in production capacity and interest rates*.

\section{Changes in the financial markets}

Since the breakdown of the Bretton Woods international agreements, exchange and interestrate instability on the major financial markets has led to genuine structural changes in those markets, although there is still no sign of any new financial structures capable of offering the stable long-term financing essential for the expansion of production capacities.

A recent IMF study (1998) distinguishes between the various types of crisis. It stresses that the banking crises of the past 10 years, the Mexican and Asian crises included, are producing global effects and finds that they can be attributed to financial deregulation and liberalization processes and to the part played by flows of international capital and by financial innovation in the run-up to the new millennium.

Essential elements for embarking on a phase of stable, long-term economic growth accordingly appear to be the re-establishment of exchange rules and the stabilization of interest rates. The structural financial changes that have occurred over the past 25 years include the following:

(1) The time schedules for financial deposits and instruments have shortened; this has

\footnotetext{
* Editor's note: Throughout this article, the authors are using the terms 'billion' and 'trillion' in their American senses: a billion is a thousand million, i.e. $10^{9}$, with nine zeros; a trillion is a thousand billion, i.e. $10^{12}$, with twelve zeros.
}

been accompanied by the development of an active secondary market in securities, leading to a blurring of the distinctions between the various concepts of money supply. "In particular, "money" has been becoming less distinguishable from the other liabilities of financial intermediaries' (OECD, 1995, p. 10);

(2) Bank funds have changed into liabilities yielding a return and originating mainly in the money markets; there has been a growth in the securitization of credit, together with an enormous increase in the off-balancesheet operations of banks, particularly involving the use of derivatives and the management of, and trade in, securities; all this has changed the structure of bank income from one of margins to one of commissions;

(3) The dividing lines, where these existed, between deposit banks and investment banks have gradually disappeared; at the same time, activity on the money and capital markets has increased, while credit activity has declined on the markets as a whole; investment-fund activity has increased, with financial assets being highly concentrated in the hands of a few managers who shift around large volumes of assets in short periods of time, destabilizing currencies and economies as powerful as those of the United Kingdom in 1992 and as small as those of Mexico, Thailand, Indonesia and the Republic of Korea;

(4) The volume and size of financial transactions have grown rapidly; the increasing number of off-balance-sheet operations has tightened the links between financial intermediaries, a few of whom dominate the markets, and a pronounced trend has arisen towards the building up of true financial mega-conglomerates; the leading ten United States banks possess, assets of more than US \$2.6 trillion (Giron, 1998);

(5) The problems of financial supervision have grown increasingly complex; at the same time, risk-level assessment and intervention by the financial authorities are becoming more difficult despite the assistance of the Bank for International Settlements, the International Monetary Fund and the World Bank; 
(6) Government debt has become one of the most important bases for the growth in financial assets, while the interest rates offered by these instruments are the chief means used to pursue exchange-rate objectives; the United States, in particular, has had to keep interest rates for government instruments substantially higher than Japan and Germany in order to prevent a massive flight of financial assets from its market and continue financing its deficit positions;

(7) The growing inability of nation-states to regulate the activity of the major financial conglomerates in order to oversee the risk levels of their various operations casts doubt on the financial authorities' ability to control a systemic financial crisis; this ability has been steadily eroded by the growing liquidity levels generated by the intermediaries themselves.

Believing that all these changes in the financial markets are irreversible is as unrealistic as attempting to ignore the profound changes that have occurred in the ownership of assets and in monopolistic competition. In this context, François Chesnais states: 'Declaring that financial hypertrophy together with its retinue of ills is "irreversible" is to fall into a highly suspect form of historical determinism. To put it at its strongest, it would be ascribing to social processes - which are the products of human activity - a status similar to that of the processes of biological evolution. For some, uttering the word "irreversibility", often in the same breath as "realism", has always amounted to adopting a position in support of the established order ...' (Chesnais, 1996, p. 30).

As the history of finance has shown on other occasions, it is possible to return to controlled financial systems in which the state takes back its capacity to regulate and supervise financial markets and intermediaries, even though the latter and the growing fragility of the former are still part of the processes involved in the failure of the terms of surplus and wealth distribution and the new economic division of the world is still an ongoing process.

Since the breakdown of Bretton Woods and the disappearance of fixed exchange rates and of the dollar-gold exchange standard, neither national governments nor international financial bodies see any solution to the problems encountered by both developed and developing countries in finding a path to growth which will eliminate the continual financial, stock-market and banking crises into which more and more countries are falling every day.

There is a pressing need for financial markets to be given a new institutional and regulatory framework capable of restraining financial instability and of limiting the damage to production capacity, growth and job creation. The paradoxical world we live in compels us to seek answers. How often have we asked ourselves, Why so much stress on the inadequacy of savings when the volume of capital on the financial markets increases two or three times more than production every year? Why is the number of poor people in the world increasing, just when we have attained immense mastery over science and technology applied to economic activity? Why are there high rates of unemployment accompanied by growing and unsatisfied needs for food, education and health?

Why is the trend towards globalization running parallel with the increasing exclusion of most of the population from education, health services and electricity? Globalization and exclusion do not constitute a promising combination. Progress along the road to globalization has shown us that we live in one world and share the same living environment and financial crises, together with their economic and social effects.

At this end of a century and of a millennium, the opportunity arises, in many fields of knowledge and of living together around the world, to evaluate successes and set fresh goals which will offer new routes and solutions. It is also an opportunity to take up afresh the discussion on economic development and what it is exactly and, in particular, on the relevance and content of development policy.

The natural and evolutionist idea of the economic process fell by the wayside when it was challenged by the crisis of the 1920s and 1930s; it is further undermined by the current international crisis. 'Development does not contain the concept of naturalness and spontaneity involved in the evolutionist view, nor the concept of gradual and continuous change. On the contrary, development entails sweeping and deliberate transformations, structural and 
institutional changes ...' (Sunkel and Paz, 1970, p. 24).

\section{Banking crises and financial globalization}

As mentioned in the introduction, banking crises have multiplied in the last 15 years, going hand in hand with the process of international financial deregulation both in the developed and in the developing and transitional countries. Crises occur when the active management of balances comes up against currency mismatch problems; when credit is concentrated in certain sectors (for example, oil or real estate) or companies; when interest rates are high during periods of lower economic growth; when there are high leverage levels resulting from rapid privatizations or takeovers; or where there is a combination of these factors.

Recent banking crises are the outcome of the deregulation and liberalization of national financial systems and of increased competition in the financial sector. They may be preceded by monetary crises, external-debt crises, stockexchange crises or sectoral crises. Perhaps the most notable crises of the last few years have been the bank failures in Thailand, Indonesia, the Republic of Korea and Japan, as well as those in Scandinavia at the beginning of the 1990s and in Latin America since the middle of the decade: for example, Mexico, Argentina, Brazil and Venezuela. We should not forget the failure of the savings and loan associations in the United States during the 1980s which cost the Federal Reserve 500 billion dollars, nor the banking crises in Spain, the United Kingdom and Chile during the same period.

Competition between the banks and other financial intermediaries, the reduced importance of the role traditionally played by the commercial banks, the increased number of off-balancesheet operations and the participation of new financial instruments are leading to rapid transformation and sectoral conglomeration.

Many of the recent banking crises stem largely from greater competition in markets which have become increasingly integrated at world level, and from the participation of nonbanking intermediaries. In the case of developing countries and transitional economies, however, a comparative disadvantage arises inasmuch as their sources of liquidity are associated with relatively weak monetary standards.

The differentials maintained in interest rates in order to achieve a degree of currency stability tend to increase the foreign-exchange component of bank liabilities, and even the liabilities of non-bank enterprises. Abandoning the local market, an influx of short-term capital attracted by interest-rate differentials and relative currency stability quickly produces a monetary imbalance in the banks and an inability to pay on the part of non-banking corporations.

To the foregoing should be added the search for instruments yielding a better return on expanding money and capital markets and the downward trend of investment and growth rates in the world environment.

The new competition at world level which accompanies financial deregulation has turned debtor countries' traditional financing and refinancing methods towards credit securitization. At the same time the stock-exchange listing and privatization of firms has provided profitable openings for the expansion of non-banking financial services. Thus the inflow of early-maturing capital into emerging markets underwent extraordinary growth from the end of the 1980s to the mid-1990s. Net capital flows to developing countries, countries in transition and recently industrialized economies represented US\$767 billion during the period 1994-1997; developing countries, US\$655.3 billion; Latin America, US\$164.7 billion; and Asia, US\$295.6 billion. However, for this year Asia alone will receive US\$1.5 billion, while Latin America will get US\$71.7 billion. Although flows of capital into open economies are a source of financing, they are also a factor in the new forms assumed by financial crises, particularly, at the moment, the Asian crisis. If the adjustment programmes improve the macro-economic variables of the Republic of Korea, the Philippines, Indonesia, Malaysia and Thailand, these countries will experience a situation of surplus and their economies will start growing again in two years, but this ignores the social cost implicit in these economic-policy measures as well as the social implications, the most notable example covered by this remark being Indonesia.

These markets established themselves as sources of investment yielding attractive returns 
and exploited the liquidity and opportunities for arbitrage and diversification offered by the portfolios of institutional investors, pension and mutual funds, insurance companies, brokerage houses and investment banks. The annual average of net private-capital flows during the 1990-1996 period was US\$148.1 billion, of which US\$131.2 billion was accounted for by the developing countries. Altogether, these countries received US\$655.3 billion between 1994 and 1997. The Asia region received approximately 45.1 per cent and the Latin America region 38.9 per cent. The strength or weakness of a banking system is the result of macro-economic and structural policies which allow, or do not allow, a close correlation between the financial sector and the production system. In Latin America the processes of trade and finance liberalization have not been successful, precisely because they have not helped to raise investment and growth rates but instead have increased financing costs and brought about banking and financial crises. Examples of this are Chile in the early 1980s and Brazil, Venezuela, Mexico and Argentina in more recent years.

It is consequently recognized in Latin America that banking systems are vulnerable to macro-economic changes, regardless of whether they are properly regulated and supervised. They are thus sensitive to changes in demand for national currency or in external-capital flows, which are capable of undermining the ability of national banks to meet their commitments.

The fiscal cost of restructuring or bailing out banks has been very high in relation to GDP; in the Republic of Korea alone it represents 33 per cent, in Japan 31 per cent and in Mexico between 12 and 15 per cent of GDP. However, the costs of a banking crisis are larger: in addition to the fiscal cost of restructuring the financial sector, there is the effect of this process on the level of economic activity, as well as the inability of the financial markets to function efficiently for a long period. To summarize, several elements must be considered:

(1) Since the drop in international loans during the 1980s' 'debt crisis', the financial markets have reactivated their expansion towards the emerging economies through stock-exchange instruments and securities involving greater liquidity and risk. The general use of securitization gives even direct investment greater liquidity by largely blurring the distinction between it and portfolio investments in terms of their impact on external accounts (Kregel, 1998).

(2) Financial deregulation and liberalization in the various national financial systems started as a consequence of the need to increase the intermediation margins and the commissions of national banks, and the securitization of credit has produced an expansion both in off-balance-sheet activities and in non-banking financial intermediaries.

(3) At world level, a number of countries are increasing the participation of capital flows by portfolio investment abroad; this increase and the yields from these flows greatly exceed the countries' economic growth. An asymmetry is thus generated between economic growth rate and the rate of return on financial investments.

(4) Financial integration and globalization in the direction of a single, homogeneous and permanent market operating 24 hours a day stems from the technological revolution in communications, but started with the failure of Bretton Woods. The renewed pre-eminence of the dollar on the international economy as the result of a significant interest rate differential has not greatly affected its dynamism, which is due to the deregulation of the domestic financial market and to the extensive development of financial innovation (Correa, 1998).

Management and settlement of the banking crises both in the Asian and in the Latin American countries have scarcely begun. The various measures taken by governments are aimed, in accordance with IMF guidelines, at declaring bankrupt and winding up certain banks identified as insolvent, at guaranteeing deposits (so far to an unlimited extent) and at transferring redemption costs to public funds.

All this goes together with reform of the supervisory institutions and of the legal and juridical framework so as to open the way for efficient bankruptcy control and to reduce deposit-insurance coverage. The participation of nation states in the ownership of banking intermediaries is intended in any case to be temporary (bridging banks), thus permitting the speedy 
repurchase of already restructured banks by solvent banks, chiefly foreign. Progress is likewise being made towards setting up receivership firms along the lines of the winding up of savings and loan associations in the United States, which will enable rapid change to take place in the ownership of firms facing insolvency.

History shows that banking crises are very slow to be resolved. The economic capacity to cope with a volume of liquid assets in the form of deposits tied to loans to insolvent economic operators takes a long time to acquire and may entail sweeping structural adjustments. In any case, monetary austerity makes it more difficult to deal with these banking crises and causes borrowers and the banks themselves to become insolvent. The tax burden entailed in redemptions ties up a growing and substantial part of public budgets already depleted by recession. A progressive solution leading to rapid economic growth with employment requires the involvement of a wide range of political forces committed to development.

\section{Concentration in the financial markets}

Taking account both of the greater presence of non-banking financial intermediaries and of the national origin of intermediaries, the relative share of financial intermediaries on the various markets has also changed in recent years. As regards the banks, in the 1980s Japan enjoyed the highest rate of growth of external and domestic banking assets, to the point where Japanese banks displaced the major United States banks from their leading positions.

The banking system in many countries is dominated by a few large banks. The share of the five largest banks in total bank assets is around 40 per cent in Argentina, 50 per cent in India, 60 per cent in Thailand and Mexico, 13 per cent in the United States, 27 per cent in Japan, 17 per cent in Germany, 47 per cent in France, 29 per cent in Italy, 57 per cent in the United Kingdom, 65 per cent in Canada, 50 per cent in Switzerland and 49 per cent in Spain. In most of these countries the concentration is higher than in 1980. Why do financial deregulation and the new competitive framework resulting therefrom promote the conglomeration of financial services?
Examples of this are: the tie-up between Chase Manhattan and Chemical Bank and a series of bank mergers in the United States; the union between Bank of Tokyo and Mitsubishi Bank; and the recent partnership between Citycorp and Travelers.

These mergers represent a new stage of bank integration in the United States and worldwide. They are directed specifically at the fields in which the new financial power structure of global intermediaries must be set up, in addition to the new financial market, service and intermediation structure which is emerging from the financial crisis in Latin America and Asia.

In 1995-1996, the Japanese banks accounted for seven out of ten of the world's leading banks from the viewpoint of the size of their assets (excluding off-balance-sheet operations). The five leading Japanese banks reported assets exceeding US\$2.4 trillion; these five banks alone thus accounted for around 8.5 per cent of world banking assets. This enormous expansion in Japanese banking also reflected the rising value of the yen against the dollar during the 1980s and its enhanced presence on the international markets. However, because of the dollar's revival and the deep Japanese financial crisis in the late 1990s, Japanese intermediaries have had to restructure their operations on both the domestic and the international markets.

The appearance of mega-consortia following the financial mergers of the first few months of 1998 is altering this picture at an ever-accelerating pace, with a trend towards the repositioning of United States financial intermediaries in the markets, including in South East Asia.

The leading five German banks reported assets in excess of US\$1.6 trillion in 19951996, representing around 5.7 per cent of world banking assets, while the five largest United States banks handle more than US\$1 trillion, i.e. 3.6 per cent of world banking assets. ${ }^{1}$ However, the recent merger of Citycorp with Travelers will alone result in a consortium with assets exceeding US\$740 billion.

The decline in the relative position of the United States banks on the domestic and international markets during the 1980s and part of the 1990s is being rapidly reversed. The current mega-mergers, combined with their increasing relative share in 'emerging markets', is leading 
Tension on the Sao Paulo stock exchange, 18 January 1999. Marie Hippenmeyer/AFP 
to a new positioning of these intermediaries in a very short space of time.

The segmentation of financial intermediaries in the United States in the 1930s boosted the development of non-banking financial intermediaries. United States bank assets in 1994 accounted for 23 per cent of that country's total financial assets, while in Japan and Germany those assets accounted for 79 per cent and 77 per cent respectively (Bank for International Settlements, 1996, p. 126).

The presence of the United States and the dollar on the financial markets must therefore be assessed in the light of other, non-banking intermediaries. In about 1993, the share of world assets held by United States investment funds reached nearly 50 per cent. Counting both bank and fund-managed assets, the United States took up 21 per cent of the market in that year, exceeded only by Japan with 24 per cent; Germany held 4.3 per cent, while France and the United Kingdom held 6.8 per cent and 3.6 per cent respectively (Barth et al., 1996).

The considerable development of investment funds, especially in the United States, has been buoyed up mainly by credit securitization and the incorporation into the capital market of local and foreign companies, the latter as the result of a number of deregulations. United States banks themselves are sharing in the expansion of investment funds by diversifying their activities and establishing true financial conglomerates; all this is made possible by specific deregulations such as the authorization of subsidiaries of bank holding companies, the creation of Section 20 subsidiaries beginning in April 1987 and the gradual repeal of the McFadden Law.

It has not been possible to moderate, as in previous years, the imminent new international financial crisis resulting from the insolvency of banks and companies in developed countries like Japan and the Republic of Korea, in developing countries like Indonesia, Malaysia, Thailand, South Africa, etc., or in transitional countries like Russia, by means of government intervention, for example by the participation, whether concerted or not, of the central banks in the foreign-exchange markets, or the use of state resources to limit stock-market falls.

The main factor preventing the outbreak of a larger-scale crisis was the extraordinary growth in international liquidity brought about by the development and penetration of derivatives. However, during these months, and with the worsening of the crisis in August 1998, the presence of that liquidity has been weakening the markets even further and the financial authorities show a definite inability to curb it.

The derivatives market resumed its headlong development in the last years of the 1980s. It is estimated that by 1996 an underlying amount of principal representing US\$55.7 trillion had accumulated (United States General Accounting Office, 1996a). Its explosive growth has been a factor in the rise in stock markets world-wide and in 1995-1996 was accompanied by an extraordinary increase in international bank lending. Over half of all transactions on the organized market take place in the United States, 17 per cent in Japan and 21 per cent in Europe.

The leading banks and exchanges in the United States, Japan, France, the United Kingdom, Germany and Switzerland are the dominant players on the derivatives markets and the medium and small intermediaries tend to be the final users. ${ }^{2}$

There is a high degree of concentration. Fifteen members of the International Swaps and Derivatives Association accounted for 93.6 per cent of the derivatives activities of the commercial banks. Of these 15, six (Banker Trust, Bank of America, Chase, Chemical, Citycorp and Morgan) are described as 'ruling world derivatives' because they account for 89.5 per cent of the derivatives held by the 15 (Sinkey, Hiles and Carter, 1995, p. 2).

The world derivatives market is essentially controlled by a few intermediaries. There exists '... a high concentration in derivative activities. Not more than 50 world institutions currently dominate the market, with the bulk of activity being carried out by a much smaller number' (Witschi and Holzer, 1995, p. 5).

The changes in the United States financial market have also led to a strong movement towards the concentration of credit and private liquidity. In 1984, the ten major bank holding companies (BHC) controlled 17.4 per cent of bank deposits; by 1994 this figure had become 25.6 per cent (United States General Accounting Office, 1996b, p. 23). According to statistics published by The Banker magazine, the 11 
major banks held 30 per cent of total assets in 1995. The number of banking institutions fell from nearly 36000 in 1980 to almost 24000 in 1995 (not counting credit unions), while the ten largest increased their level of concentration from 14 per cent to 21 per cent of total assets. Mergers and takeovers in the sector have been increasing, their value in 1989-1990 being US $\$ 37.8$ billion, rising to US $\$ 82.5$ billion in 1995-1996. Despite the renewed dynamism of mergers and takeovers in the 1990s, the process of consolidation in the sector will continue for several more years (Bank for International Settlements, 1996).

As regards institutional investors, these include mutual funds as well as private pension funds and insurance companies. The United States holds nearly 50 per cent of the total world assets managed by those funds, followed by France with 12 per cent and Japan with 11 per cent, while Luxembourg and Germany together account for another 11 per cent (Barth et al., 1996).

In the United States alone, it is estimated that in 1993 these investors managed assets worth more than US\$8 trillion, i.e. around 125 per cent of the product, and that by 1996 this figure could exceed US\$13 trillion, i.e. 180 per cent of the product (Farnetti, 1996, p. 192).

One of the most important fund-controlling firms is Fidelity Investment, which at the beginning of 1996 was managing assets worth around US $\$ 416$ billion. The mutual funds alone - some 5600 of them - are estimated to have been managing assets worth US\$2.5 trillion at the beginning of 1995 . This figure may reach US\$3 trillion in 1998.

Institutional investors, particularly those of the United States, have played a prominent role in the flow of capital into and out of the financial markets of countries with 'emerging markets'. In the case of Mexico, the principal investors have been: Fidelity, Scudder, Merril Lynch, Oppenheimer, Putman Funds Management, March and McLennan Co., Soros Fund Management, Salomon Bros. Inc., Nomura Securities Co. and Weston Bank; there have also been other investments managed by banks such as J. P. Morgan, CS First Boston and Citycorp (Correa, 1997).

United States commercial banks operating as BHCs have been expanding their investment- banking operations through Section 20 branches. The financial authorities again expanded their capacity to engage in securities-trading activities at the beginning of 1997.

Penetration of Latin America by foreign banks has been startling. Citibank, for example, has assets worth US $\$ 28$ billion in 26 countries, while the Bank of Boston has assets of US\$14 billion in six countries. Banco Santander brings together banks included among the ten leading banks of countries such as Argentina, Colombia, Mexico, Peru and Venezuela. The Bank of Nova Scotia has the controlling option on two of the largest banks in Argentina and Mexico, and also has holdings in Chile, Peru and Venezuela and in two banks in Central America. The $\mathrm{BCH}$ and its strategic partner, Banco Comercial Portugues, have a commercial bank in Mexico. Citibank recently initiated a strategy of bank acquisitions in Latin America. Similarly, the Bank of Boston recently announced its acquisition of Deutsche Bank of Argentina, an operation likely to make it the second largest bank in the country and equip it to deal more efficiently with future inflows of foreign capital.

Keen competition between financial intermediaries with regard to the formation of highyield assets in the most varied currency denominations is increasing concentration and centralization in the form of large financial conglomerates, although this does not necessarily mean an improved competitive position. The prices of bank shares, for example, in countries like the United States, Germany, Italy, Finland, Norway, the Netherlands, Spain, Switzerland and Sweden, are below 1980 levels. Earnings as a percentage of assets have fallen from their 1980 levels in countries like Japan, France, the United Kingdom, Finland, Norway and Spain. At the same time, income other than interest charges for credit has risen substantially since 1980 for banks belonging to countries such as the United States, France, the United Kingdom, Canada, the Netherlands, Finland, Norway, Sweden and Spain, as a result of which credit proper is being replaced in banking operations by trade in securities.

All this has not necessarily led to greater efficiency as regards the availability of adequate, stable and low-cost resources for investment. Real interest rates have tended to rise substantially in the major economies during 
the 1990s and, since the 1980s, have stayed well above the economic growth rate in the group of most highly developed economies. The high real rates of interest resulting from increasing financial fragility and instability - together with surcharges for the various risks (exchange, systemic, moral, etc.) - are becoming incompatible with increased productivity and with the payment capacity of many firms, particularly those operating on the markets of countries with weak currencies.

The increasing participation of foreign financial intermediaries in developing countries does not necessarily lead to a greater availability of resources for productive local financing which will be both stable and cheap, because their activities do not in themselves reduce exchange-risk surcharges or ensure a drop in bank margins. In Mexico, for example, their operations are focused on corporate services, particularly consumer credit and investment funds. Their profitability will depend both on expansion of their share of the corporate market and on the share they have of the exchange and money markets. They are appearing on the scene in increasing numbers, particularly as providers of foreign-currency funds to local banks, thus establishing themselves as a determining factor in the cost of financing in both national and foreign currency. National banks are thus not only yielding ground on the local market but also losing the power to impose their own asset and liability management strategy on that market.

The risk of losing national control over the payment system thus arises from two factors: first, the inability of the local bank to restore the payment capacity of insolvent bank borrowers and, second, the increase in the number of foreign financial intermediaries, who gradually impose their own margin and cost structure on the operation of the banking system as a whole.

\section{State and market: stable development financing}

In the context of freedom of capital movement, the heavy concentration of sources of national and international liquidity in the hands of private operators has not led to a sustained long-term recovery of development financing. On the contrary, it generates a new level of competition leading to the denationalization of developmentfinancing systems and strengthens the conditions favouring the transfer of local savings towards the return to be obtained from typically very short-dated capital with a high expected yield. At the same time, it does nothing to solve, especially in the short and medium terms, the problems of financial fragility occasioned by the enormous differential between the returns required on such capital and increases in local productivity and profitability. This phenomenon manifests itself with ever greater force in continual bankruptcies and liquidations of local and national intermediaries, even where these had resisted the first onslaught of the banking crisis.

Again, the logic of this international mobility of capital accompanied by high financial concentration necessarily results in a change in the ownership of the assets, and even the fiscal resources, of nation-states. This, however, is not reflected in a flow of stable low-cost financing that increases local production capacities and employment.

Once penetration by highly concentrated foreign financial intermediation is well under way and the processes of privatizing leading local companies and integrating them into the financial market have been carried out, with the local markets being divided among the major international corporations, it will undoubtedly be possible to manage the problem of exchangerate stability through monetary-integration processes. However, the resulting financial fragility and instability impose a high cost in the form of the destruction of production capacities and employment, with no hope of recovery in the short and medium terms.

Financial opening up and liberalization in economies such as those known as 'emerging markets', in the economies of countries in transition, or even in developed economies like the Japanese, jeopardize monetary sovereignty (De Brunhoff, 1996; Kregel, 1996).

The recent international financial crisis highlights the inability of local financial authorities to cope with it and the need to have recourse to the United States Federal Reserve and the International Monetary Fund as lenders of last resort. 
Once the coherence of areas of national production has been broken, financing terms remain subject to the movements of the international financial markets and particularly to the US dollar; references to earnings and prices are likewise dollar-denominated. However, a sizeable volume of transactions and productive assets, including wages, continues to be controlled and is dealt with in terms of local currencies, which leads to a deflationary process accompanied by over-indebtedness and exchange-rate deterioration.

All this indicates that during the integration process those areas which have been liberalized in this way will, if the present course is maintained, culminate in more thorough monetary integration, provided only that certain sectors crucial to the transnational expansion of the corporations, particularly those corporations tied to the US dollar, become part of their assets (Correa, 1998).

The transfer of a substantial part of fiscal resources to the sphere of financial-income distribution, together with the rise in privatizations, takeovers and mergers, is currently a matter of interest to the financial mega-conglomerates. To a large extent, if such a strategy is to do well, it will be essential to make changes in local legal systems and to bring about greater deregulation in financial markets, including the United States market. Consequently, the immediate path to be followed by the financial-globalization process, which includes monetary integration, is strongly determined by the particular form in which some of the main disputes are settled in the political field. In the case of the relationship between Japan and the United States, such disputes concern the progress of liberalization, financial opening up and reforms in financial legislation.

The financial opening up and deregulation now in progress mean, for many countries, not only surrendering their sovereignty and ceasing to control monetary policy but also, and especially, losing the capacity to utilize surpluses, mobilize their resources and expand credit for the process of accumulation. An economic and political problem therefore arises when the financing of accumulation is carried out from another political area.
The opening up and liberalization of financial markets have represented the key point at which a particular form of competition and distribution of surplus is broken. Local price, productivity and profitability structures are reorganized, and this gives rise to a process of international conglomeration in many productive sectors such as telephony and telecommunications, the car industry, electronics, energy and oil, etc. Such conglomeration is increasingly incompatible with the institutional structures of political and social management in nation states in that it fails to address the democratic expectations of populations, which are insisting more and more on taking a hand in building their own future.

It is therefore important on economic, political and social grounds to construct new terms of development co-operation in which cooperation with a view to financial stability is a priority.

\section{Conclusions}

The Asian crisis and the international repercussions of the stock-exchange falls in October 1997 and April and August 1998 signal the beginnings of an economic crisis like that of the 1930s which calls into question hegemonic economic policy, flows of international capital, financial bodies themselves and the international monetary system. The recent slowdown in the economies of China and the United States during the second quarter of 1998, recessionary expectations in Japan, the consequences of the banking crises and the insolvency of numerous debtor governments and companies jeopardize the viability of the policies orchestrated up to now and place the need for a sweeping reform of international financial relations on the agenda. The lack of prudential regulation, and the integration of production at global level under the control of transnational conglomerates, leaves nation-states in a situation of downright weakness when it comes to achieving stable economic development which will ensure sustained growth, better income distribution and higher employment.

Translated from Spanish 


\section{Notes}

1. It should be pointed out that these statistics are based only on banking assets and take no account of off-balance-sheet transactions, which have increased significantly throughout the banking world, but particularly in the United States.
2. With regard to United States banks, a study has shown that user banks (both final and intermediate users) have weak capital positions, substantial asset growth and heavier charges on net loans, pay out more earnings in the way of dividends and use more notes and bonds to finance assets (Sinkey, Hiles and Carter, 1995, p. 2).

\section{References}

BANK FOR INTERNATIONAL Settlements, 1996. Annual Report, Basle.

BARTh, R. J. et al., 1996. 'Commercial Banking Structure, Regulation and Performance: An International Comparison', International Trade and Finance Association Sixth Annual Conference, May, San Diego, California.

Chesnais, F., Co-ordinator 1996. La Mondialisation Financiere (Financial Globalization). Syros, Paris.

Correa, E., 1997. 'Foreign Portfolio Investment and Mexican Financial Crisis', Journal of Emerging Markets. St John University, New York.

Correa, E., 1998. Crisis y Desregulacion Financiera (Financial Crisis and Deregulation). Siglo Veintiuno Editores, Mexico.

De Brunho,FF, S.,, 1996.

'L'instabilite Monetaire Internationale' (International Monetary Instability), in Chesnais, 1996.
FARNetTI, R., 1996. 'Le role des fonds de pension et d'investissement collectifs anglosaxons dans l'essor de la finance globalisee' (The Role of AngloAmerican Pension and Collective Investment Funds in the Expansion of Globalized Finance), in

Chesnais, 1996.

World Economy Outlook. International Monetary Fund, 1998, Washington.

Giron, A., 1998. 'Crisis Financiera del Sudeste Asiatico: Mutaciones Financieras y Crisis Bancarias' (South-East Asian Financial Crisis: Financial Changes and Banking Crises), to be published in Comercio Exterior (Foreign Trade), Mexico

Kregel, J., 1996. 'Some Risks and Implications of the Financial Globalization for National Policy

Autonomy', UNCTAD Review,

Geneva.

Kregel, J., 1998. 'Flujo de capitales, fragilidad e inestabilidad financiera en el desarrollo economico' (Capital flow, fragility and financial instability). Giron, A. and Correa, E. (co-ordinators), Crisis Financiera: Mercado sin Fronteras (Financial Crisis: Market without Frontiers), Ediciones El Caballito, Mexico.
The New Financial Landscape. Organisation for Economic Cooperation and Development (OECD) 1995, Paris.

Sinkey, J.; Hiles, E.; Carter, A., 1995. 'The Determinants of Hedging and Derivatives Activities by US Commercial Banks', American Finance Association Meeting, Washington.

Sunkel, O.; Paz, P., 1970. El Subdesarrollo Latinoamericano y la Teorla del Desarrollo (Latin American Underdevelopment and Development Theory). Siglo Veintiuno Editores, Mexico.

United States General Accounting Office, 1996a. Bank Oversight Structure, Washington.

United States General Accounting OfFice, 1996b. Financial Derivatives, November 1996, Washington.

Witschi, D.; Holzer, S., 1995. 'The rise of new markets - some characteristics', Economic and Financial Prospect, Swiss Bank Corporation, Geneva. 